\title{
Study of Stress among Health Care Professionals: A Systemic Review
}

\author{
${ }^{1}$ Arvind Kushal, ${ }^{2}$ Shakti K Gupta, ${ }^{3}$ Manju Mehta, ${ }^{4}$ Madhav M Singh
}

\begin{abstract}
Stress is any action that places special physical or psychological demands upon a person, anything that can unbalance his individual equilibrium. Work-related stress is a potential cause of concern in health care workers and is associated with decreased job satisfaction, days off work, anxiety, depression, sleeplessness, medical errors, and near misses. To compare stress levels in different groups of health care worker and identify causes of stress, we conducted a survey-based study at a super-specialty public sector hospital at Delhi NCR.
\end{abstract}

Keywords: Health status, Medical practitioners, Stress, Stress management, Work stress.

How to cite this article: Kushal A, Gupta SK, Mehta M, Singh MM. Study of Stress among Health Care Professionals: A Systemic Review. Int J Res Foundation Hosp Healthc Adm 2018;6(1):6-11.

Source of support: Nil

Conflict of interest: None

\section{INTRODUCTION}

Stress is any action that places special psychological or physical demands upon a person, anything that can unbalance his or her individual equilibrium. ${ }^{1,2}$ Decreased job satisfaction inevitably results in negative results and in negative attitudes toward one's work, family, and ultimately, self. ${ }^{3-5}$

Chronic overstress often state as burnout. ${ }^{6}$ Emotional illnesses can lead to anxiety disorders, addictions, depression, eating disorders, and suicide. ${ }^{7,8}$

\footnotetext{
${ }^{1}$ Director, ${ }^{2}$ Medical Superintendent, ${ }^{3}$ Professor, ${ }^{4}$ Assistant Registrar

${ }^{1}$ Department of Hospital Administration, Ministry of Defence New Delhi, India

${ }^{2}$ All India Institute of Medical Sciences, Dr. R P Centre for Ophthalmic Sciences, New Delhi, India

${ }^{3}$ Department of Psychiatry, All India Institute of Medical Sciences New Delhi, India

${ }^{4}$ Department of Hospital Administration, Military Hospital, Meerut Uttar Pradesh, India

Corresponding Author: Madhav M Singh, Commanding Officer, 322 Fd Hospital C/O 56 APO, New Delhi-110001, India e-mail: mmsingh2011@gmail.com
}

A recent study conducted at Mayo Clinic revealed that $60 \%$ of American physicians at times suffer symptoms of fatigue and depression, otherwise known as "burnout."

Despite the high prevalence of stress in doctors, and a myriad of physical and mental health consequences, doctors are notoriously reluctant to seek help for themselves. ${ }^{11}$ Doctors are also "poor" patients due to maladaptive health behaviors. ${ }^{12,13}$

\section{AIMS AND OBJECTIVES}

\section{Aim}

The aim of the study is to assess the stress levels among health care professionals and finding its correlation with work, health status, and allied factors.

\section{Objectives}

- To assess the stress level among various work groups of health care professionals

- To explore the relation between work stress and health

- To compare the stress levels among men and women

- To explore the relation between work stress and years of work experience

- To explore marital status' influence on stress condition

- To identify the age groups which are most susceptible to work stress

\section{MATERIALS AND METHODS}

\section{Study Setting}

We conducted an anonymous survey of doctors working in various departments and in hospital administration over 6 weeks using the validated questionnaire developed by the Indian Council of Medical Research (ICMR). The study was conducted on 600 participants who included health care professionals.

\section{Study Design}

The study was a questionnaire-based analytical study incorporating two questionnaire-based tools. First questionnaire was used to asses work stress and second for general health status evaluation. The responses were statistically analyzed by Statistical Package for the Social Sciences which was used for both data analysis and tabular presentation. Descriptive statistical measures were used 
for quantitative variables. Analytic measures were done by Mann-Whitney test and Spearman correlation coefficient. The level of significance for this study was $\mathrm{p} \leq 0.05$.

\section{Study Questionnaire}

The study was done using two questionnaire-based tools which were given to 600 participants.

The first questionnaire, the work stress questionnaire (Annexure A), has been developed by ICMR, having 32 questions to be scored on $1 / 2 / 3 / 4$ criteria, Never-1, Sometimes-2, Frequently-3, and Always-4. The scores were interpreted as:

- Scores 32 to 64: You manage your stress levels very well. Too little stress can reduce stimulation, so strive to achieve the balance between negative and positive stress.

- Scores 65 to 95: You have a reasonably safe level of stress, but certain areas need improvement.

- Scores 96 to 128: Your level of stress is too high. You need to develop new strategies to improve it.

The second questionnaire which assesses commonly experienced stress symptoms (Annexure B) was developed by ICMR. The questionnaire has 30 questions which were specific to general health. Each question had symptoms needed to be scored $0 / 1 / 2$ on the criteria Never- 0 , Sometimes-1, and Always-2. The scores were interpreted as, score less than 30 meaning health is not effected, and score more than 30 meaning commonly experienced stress symptoms have effect on individuals' health.

\section{Response Rate}

The questionnaire was distributed to 600 participants out of whom 329 responded. Respondents included doctors,

Table 1: Work stress

\begin{tabular}{ll}
\hline Good & $41 \%$ \\
Needs improvement & $59 \%$ \\
\hline
\end{tabular}

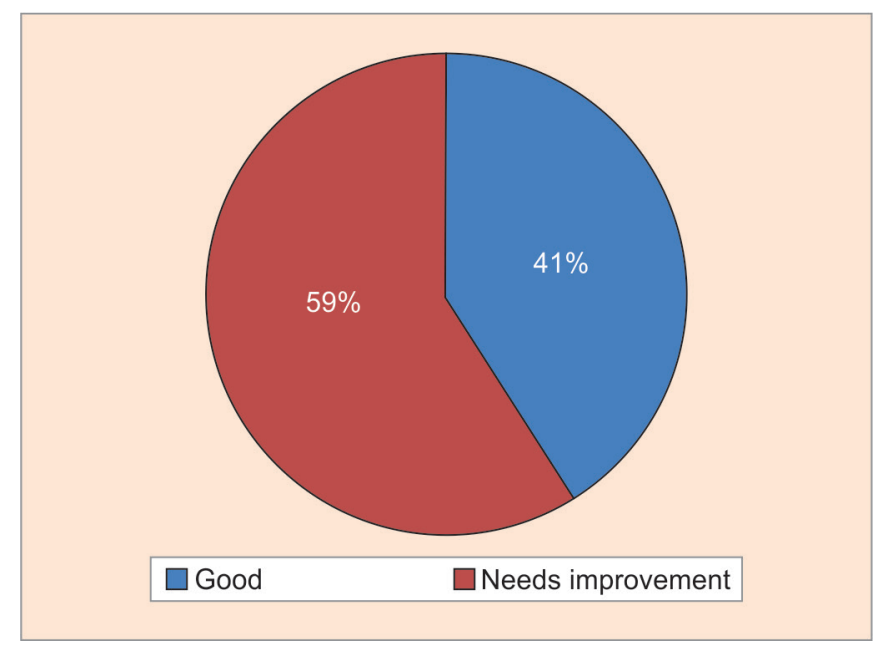

Graph 1: Work stress engineers, health care administrators, students pursuing degrees in hospital administration, and other professionals. The satisfactory response rate probably reflects both the suitability of the study design and the health care professionals' interest in the topic.

\section{OBSERVATION AND DISCUSSION}

\section{Work-related Stress}

Of the study population, 59\% (193) scored 65 to 95, i.e., having moderate stress which needs better stress management; $41 \%$ of the study population (136) scored 32 to 64 , i.e., they have safe levels of stress and they manage stress levels very well (Table 1 and Graph 1).

\section{Health Status}

Of the study population, 62\% (205) showed a stressassociated symptom; $38 \%$ of the study population (124) showed good health status (Table 2 and Graph 2).

\section{Impact of Stress on Health}

Refer to observation 1. Out of the population that managed work stress well (136), only $46 \%$ showed symptoms, whereas out of the population that did not show good stress management (193), 74\% showed symptoms. Thus, it proves that better stress management decreases the chance of having health symptoms related to stress. This result is statistically significant and the difference between two population is $74 \%-46 \%=28 \%$ (Table 3 and Graph 3 ).

\section{Job Profile and Stress}

From the total population ( $n=329)$, to find the correlation of stress in health care professionals vs other

Table 2: Health status

\begin{tabular}{ll}
\hline Affecting health & $62 \%$ \\
Not affecting health & $38 \%$ \\
\hline
\end{tabular}

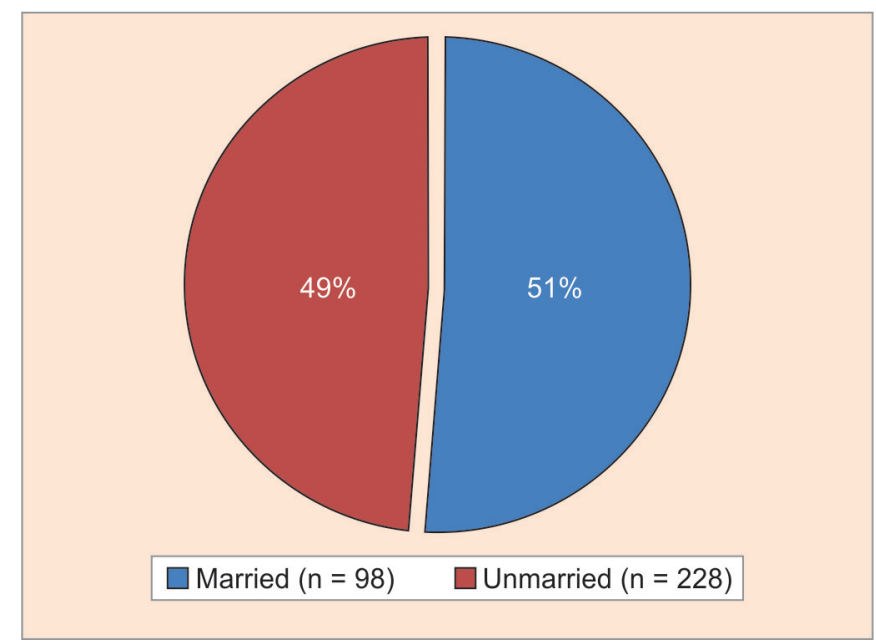

Graph 2: Health status 


\begin{tabular}{lr}
\hline \multicolumn{2}{c}{ Table 3: Impact of stress on health } \\
\hline Low stress $(n=136)$ & $46 \%$ \\
High stress $(n=193)$ & $74 \%$
\end{tabular}

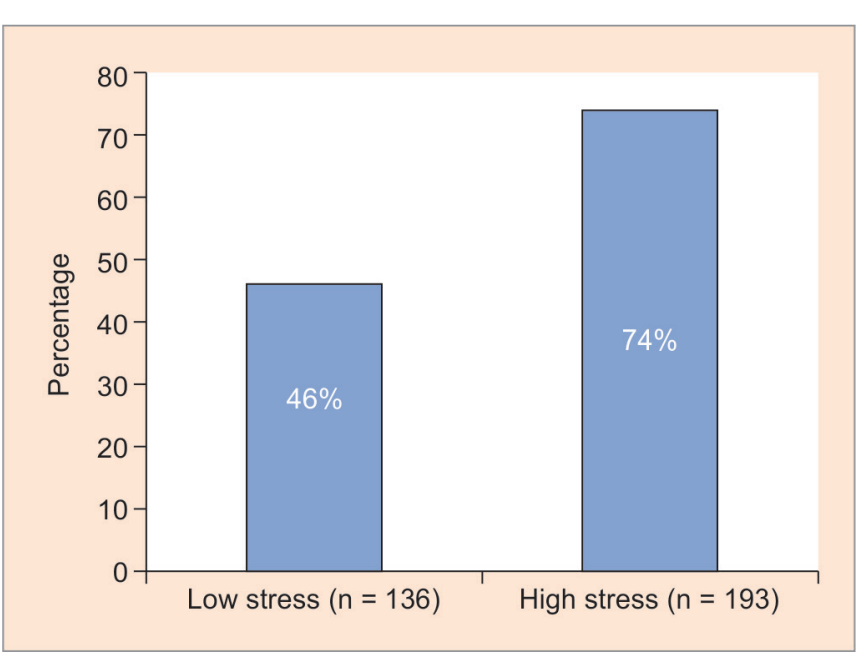

Graph 3: Impact of stress on health

professionals, student/nonworking category of sample size was excluded. The working professionals of all categories had a sample size of $125 ; 84$ out of 125 were health care professionals and $60 \%$ of these health care professionals showed stress; 41 out of 125 were nonhealth care professionals and $58 \%$ of these nonhealthcare professionals showed stress. This shows that stress level in health care professionals was marginally higher $(2 \%)$ than in nonhealthcare professionals. This result was statistically not significant (Table 4 and Graph 4).

\section{Work Experience and Stress}

The sample population was divided into three groups:

1. People having 0 to 10 years of work experience-stress in $65 \%$ of population.

2. People having 10 to 20 years of work experiencestress in $55 \%$ of population.

3. People having more than 20 years of work experiencestress in $51 \%$ of population

It is observed that as number of years of experience increase, stress management skills improve and the person copes with stress in a better way. This may not mean that stress reduces with the number of years of work, but only shows that a person handles stress in a more matured way (Table 5 and Graph 5).

\section{Age and Stress}

The population was classified into three groups:

1. People aged 20 to 30 years $[n=226$, standard deviation (SD) 0.39$]-58 \%$ of this population showed stress.
Table 4: Job profile and stress

Health professional involved in clinical area $(n=84)$ $60 \%$ Health professional working in administrative area $(n=41)$

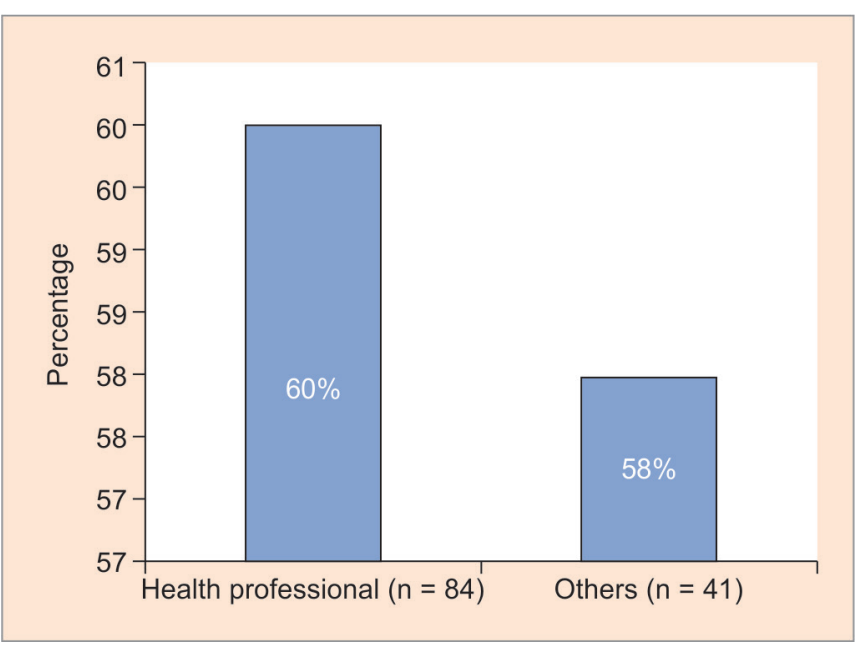

Graph 4: Job profile and stress

Table 5: Work experience and stress

\begin{tabular}{ll}
\hline $0-10(n=240)$ & $60 \%$ \\
$10-20(n=29)$ & $55 \%$ \\
Above 20 $(n=41)$ & $51 \%$ \\
\hline
\end{tabular}

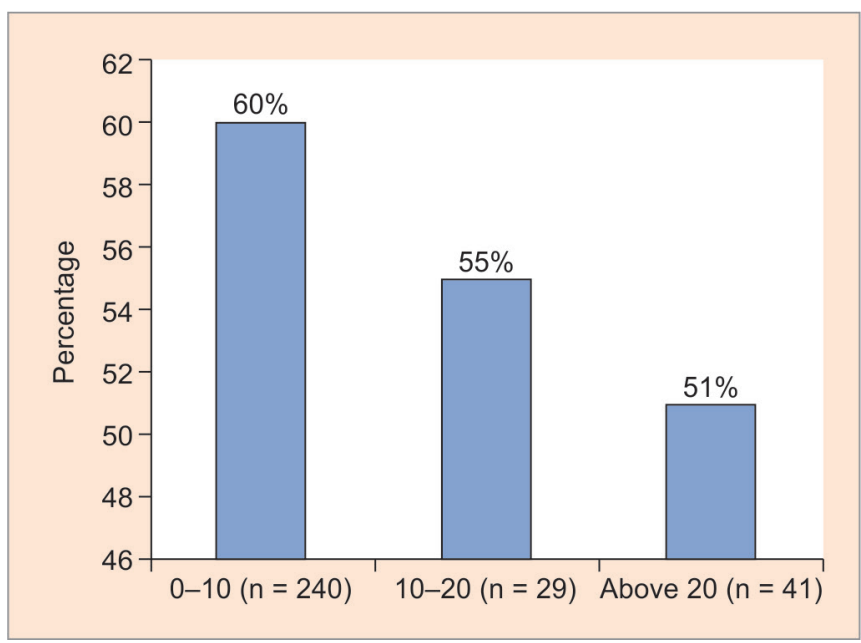

Graph 5: Work experience and stress

2. People aged 30 to 50 years ( $n=63$, SD 0.41$)-56 \%$ of this population showed stress.

3. People aged 50 years and above $(n=21$, SD 0.44$)-$ $62 \%$ of this population showed stress (Table 6 and Graph 6).

Spearman correlation revealed that there is significant negative correlation between age and total number of stress sources $(r=-0.188)$, work experience and stress $(r=-0.189)$, and job profile and stress $(r=-0.212)$. Total 
Table 6: Age and stress

\begin{tabular}{ll}
\hline $20-30$ years $(n=226$, SD 0.39) & $58 \%$ \\
$30-50$ years $(n=63$, SD 0.41) & $56 \%$ \\
Above 50 years $(n=21$, SD 0.41) & $62 \%$ \\
\hline
\end{tabular}

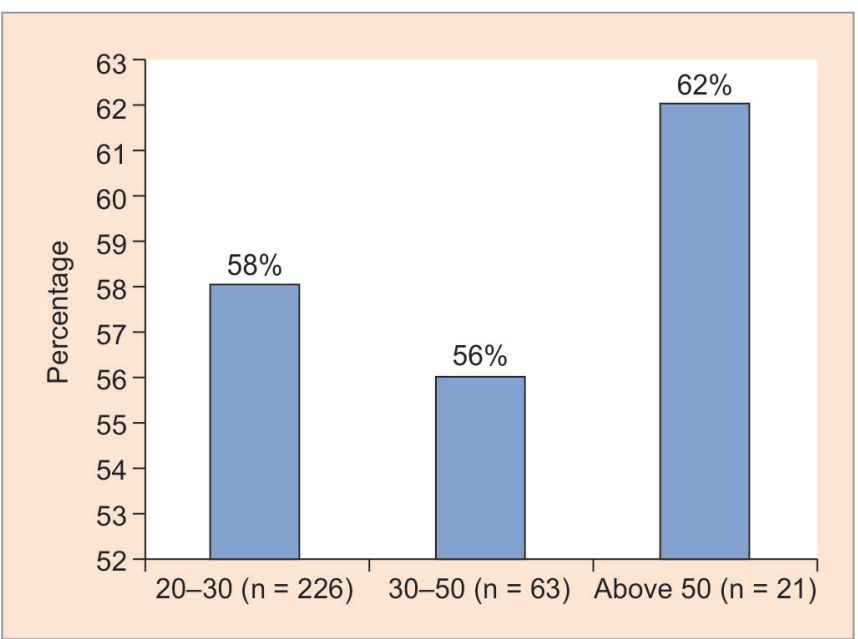

Graph 6: Age and stress

working years as a health care professional significantly negatively correlated with sources of stress $(\mathrm{r}=-0.176)$, work experience and stress $(\mathrm{r}=-0.189)$, and job profile and stress $(\mathrm{r}=-0.196)$.

Table 7: Gender and stress management

\begin{tabular}{ll}
\hline Male $(n=144)$ & $60 \%$ \\
Female $(n=185)$ & $58 \%$ \\
\hline
\end{tabular}

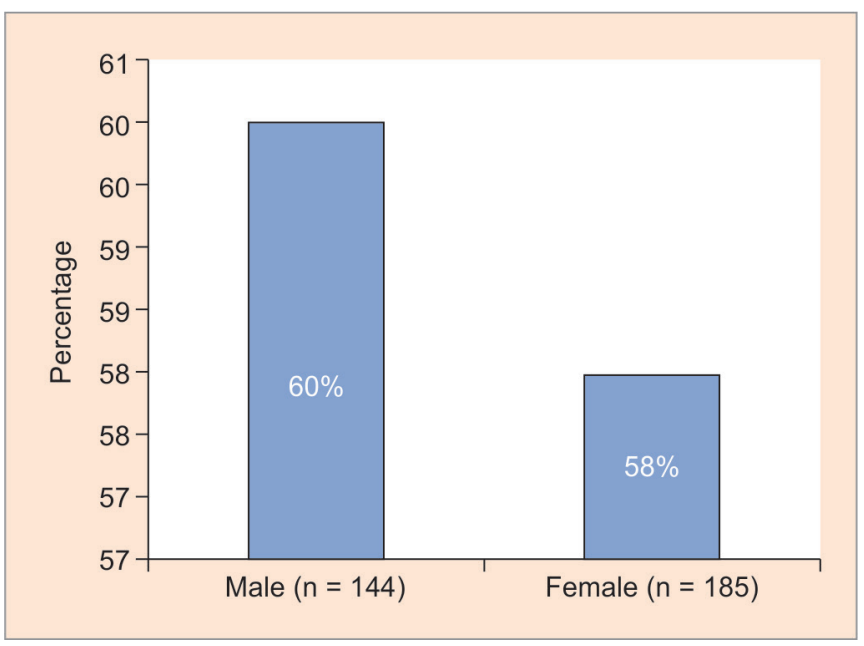

Graph 7: Gender and stress management

\section{Gender and Stress Management}

Males ( $n=144), 60 \%$ of the population had stress. Females $(\mathrm{n}=185), 58 \%$ of the population had stress (Table 7 and Graph 7$)$. Gentlemen have marginally more stress ( $2 \%)$ than ladies!!!

\section{Marital Status and Stress}

Married ( $\mathrm{n}=98), 60 \%$ of the population had stress. Unmarried ( $n=228), 57 \%$ of the population had stress. Married people have marginally higher stress (3\%) than unmarried people (Table 8 and Graph 8).

\section{CONCLUSION}

From the study, it is apparent that correlation exists between work stress and poor health. Poor health in turn, reduces human efficiency due to lack of alertness, focus, absenteeism, and other similar problems. There was no significant difference in stress levels between different grades of doctors and administrative staff. All workers in health care profession are equally stressed.

Effective stress-free environment is possible in any organization when both employees and employers cooperate and develop mutual understanding for each other's needs. ${ }^{14}$ Thus, it is essential for each of them to do their bit, to promote a wholesome atmosphere of peace, joy, and good health.

Table 8: Marital status and stress

\begin{tabular}{ll}
\hline Married $(n=98)$ & $60 \%$ \\
Unmarried $(n=228)$ & $57 \%$ \\
\hline
\end{tabular}

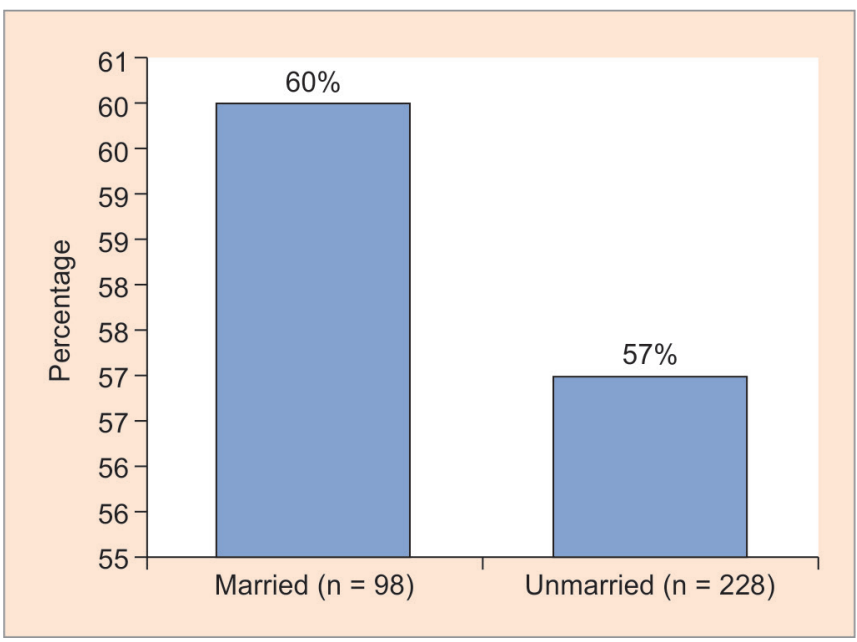

Graph 8: Marital status and stress 
ANNEXURE A

Work Stress Questionnaire Id No.

Personal Information

\begin{tabular}{lll}
\hline Name (Optional) & & \\
Age & & \\
Sex & $\square$ Male & $\square$ Female \\
Marital status & $\square$ Married & $\square$ Single \\
Education & $\square$ Nongraduate & $\square$ Graduate \\
& $\square$ Postgraduate & $\square$ Higher Education \\
Job profile & $\square$ Student & $\square$ Doctor (Clinician) \\
& $\square$ Hospital Administrator & $\square$ Entrepreneur \\
Work experience & $\square$ Engineer/Architect & $\square$ Other Professionals \\
& $\square 0-10$ yrs & \\
& $\square 10-20 \mathrm{yrs}$ & \\
\hline
\end{tabular}

\section{WORK STRESS}

\section{Part I: Instructions}

When answering this questionnaire be as honest as possible. If your answer is "NEVER" mark 1, 2—“Sometimes," 3-“Frequently," "ALWAYS" mark 4, and so on.

I blame myself when things go wrong
I bottle up my problems, then feel like I want to explode
I concentrate on work to forget about my personal problems
I take out anger and frustration on those nearest to me
I notice negative changes in my behavioral patterns when I am under
pressure
I focus on the negative rather than the positive aspects of my life
I feel comfortable when experiencing new situations
I feel that the role I play within my organization is worthless
I arrive late for work or important meetings
I respond negatively to personal criticism
I feel guilty if I sit down or do nothing for an hour
I feel rushed even if I am not under pressure
I have insufficient time to read as often as I would like
I demand attention or service immediately
I avoid expressing my true emotions at work
I undertake more tasks than I can handle at once
I resist taking advice from colleagues and superiors
I ignore my own professional or physical limitations
I miss out on my hobbies and interests because my work takes up all
my time

I am too busy to have lunch with my friends and colleagues during the week

I put off confronting and resolving difficult situations when they arise

People take advantage of me when I do not act assertively

I am embarrassed to say when I feel overloaded with work

I avoid delegating tasks to others

I deal with tasks before prioritizing my workload

I find it difficult to say no to requests and demands

I feel I have to finish all outstanding work each day

I think I will not be able to cope with my workload

My fear of failure stops me from taking action

My work life tends to take priority over my family and home life

I become impatient if something does not happen at once
$\square$ 1-Never
$\square$ 2-Sometimes
$\square$ 1-Never
-1-Never
$\square$ 1-Never
$\square$ 2-Sometimes
$\square$ 2-Sometimes
$\square$ 2-Sometimes
$\square$ 1-Never
$\square$ 2-Sometimes
$\square$ 1-Never
$\square$ 1-Never
口1-Never
-1-Never
-1-Never
-1-Never
$\square$ 1-Never
$\square$ 1-Never
$\square$ 1-Never
$\square$ 1-Never
$\square$ 1-Never
$\square$ 1-Never
口1-Never
口1-Never
$\square$ 1-Never
$\square$ 2-Sometimes
$\square$ 2-Sometimes
$\square$ 2-Sometimes
$\square$ 2-Sometimes
$\square$ 2-Sometimes
$\square$ 2-Sometimes
$\square$ 2-Sometimes
$\square$ 2-Sometimes
$\checkmark$ 2-Sometimes
$\square$ 2-Sometimes
$\square$ 2-Sometimes
$\square$ 2-Sometimes
$\square$ 2-Sometimes
$\square$ 2-Sometimes
$\square$ 2-Sometimes
$\square$ 2-Sometimes
口1-Never
$\square$ 2-Sometimes
口1-Never
口1-Never
口1-Never
$\square$ 1-Never
$\square$ 1-Never
$\square$ 1-Never
口 1-Never
-1-Never
-1-Never
$\square$ 1-Never
$\square$ 2-Sometimes
$\checkmark$ 2-Sometimes
2-Sometimes
$\square$ 2-Sometimes

$\square$ 3-Frequently

$\square$ 3-Frequently

$\square$ 3-Frequently

$\square$ 3-Frequently

$\square$ 3-Frequently

$\square$ 3-Frequently

$\square$ 3-Frequently

$\square$ 3-Frequently

$\square$ 3-Frequently

$\square$ 3-Frequently

$\square$ 3-Frequently

$\square$ 3-Frequently

$\square$ 3-Frequently

$\square$ 3-Frequently

$\square$ 3-Frequently

$\square$ 3-Frequently

$\square$ 3-Frequently

$\square$ 3-Frequently

$\square$ 3-Frequently

$\square$ 3-Frequently

$\square$ 3-Frequently

$\square$ 3-Frequently

$\square$ 3-Frequently

$\square$ 3-Frequently

$\square$ 3-Frequently

$\square$ 3-Frequently

$\square$ 3-Frequently

$\square$ 3-Frequently

$\square$ 3-Frequently

$\square$ 3-Frequently

$\square$ 3-Frequently

$\square$ 3-Frequently $\square$ 4-Always
$\square$ 4-Always
$\square$ 4-Always
$\square$ 4-Always
$\square$ 4-Always
$\square$ 4-Always
$\square$ 4-Always
$\square$ 4-Always
$\square$ 4-Always
$\square$ 4-Always
$\square$ 4-Always
$\square$ 4-Always
$\square$ 4-Always
$\square$ 4-Always
$\square$ 4-Always
$\square$ 4-Always
$\square$ 4-Always
$\square$ 4-Always
$\square$ 4-Always
$\square$ 4-Always
$\square$ 4-Always
$\square$ 4-Always
$\square$ 4-Always
$\square$ 4-Always
$\square$ 4-Always
$\square$ 4-Always
$\square$ 4-Always
$\square$ 4-Always
$\square$ 4-Always
$\square$ 4-Always
$\square$ 4-Always
$\square$ 4-Always 


\section{ANNEXURE B}

\section{Part II: Instructions}

Given below is a list of commonly experienced problems. If you do not have the problem mark 0; sometimes mark 1 , always have problem mark 2.

\begin{tabular}{|c|c|c|c|}
\hline Blurred vision & $\square$ 0-Never & 1-Sometimes & $\square$ 2-Always \\
\hline Asthma & $\square 0$-Never & $\square$ 1-Sometimes & $\square$ 2-Always \\
\hline Excessive sweating & $\square 0$-Never & $\square$ 1-Sometimes & $\square$ 2-Always \\
\hline Pain in the chest & $\square 0$-Never & $\square$ 1-Sometimes & $\square$ 2-Always \\
\hline $\begin{array}{l}\text { Palpitation (fast heart } \\
\text { beat) }\end{array}$ & $\square$ 0-Never & $\square$ 1-Sometimes & $\square$ 2-Always \\
\hline Difficulty in breathing & $\square 0$-Never & $\square$ 1-Sometimes & $\square$ 2-Always \\
\hline Cold hands and feet & $\square 0$-Never & $\square$ 1-Sometimes & $\square$ 2-Always \\
\hline Stomach upset/pain & $\square$ 0-Never & $\square$ 1-Sometimes & $\square$ 2-Always \\
\hline $\begin{array}{l}\text { Indigestion/ } \\
\text { constipation }\end{array}$ & $\square 0$-Never & $\square$ 1-Sometimes & $\square$ 2-Always \\
\hline Nausea/vomiting & $\square$ 0-Never & $\square$ 1-Sometimes & $\square$ 2-Always \\
\hline Loss of appetite & $\square 0$-Never & $\square$ 1-Sor & $\square$ 2-Always \\
\hline appetite & $\square 0$-Never & $\square$ 1-Sor & $\square$ 2-Always \\
\hline Pain in joint/back/legs & $\square 0$-Never & $\square$ 1-Sometimes & $\square$ 2-Always \\
\hline $\begin{array}{l}\text { Itching in some parts } \\
\text { of the body }\end{array}$ & $\square$ 0-Never & $\square$ 1-Sometimes & \\
\hline Headache & $\square$ 0-Never & 1-Sometimes & $\square$ 2-Always \\
\hline Panting & $\square 0$-Never & $\square$ 1-Sometimes & $\square$ 2-Always \\
\hline Biting nails & $\square 0$-Never & $\square$ 1-Sometimes & $\square$ 2-Always \\
\hline Feeling tired & $\square 0$-Never & $\square$ 1-Sometimes & $\square$ 2-Always \\
\hline Weight loss/gain & $\square 0$-Never & $\square$ 1-Sometimes & $\square$ 2-Always \\
\hline Sleep disturbances & $\square 0$-Never & $\square$ 1-Sometimes & $\square$ 2-Always \\
\hline Losing temper & $\square 0$-Never & $\square$ 1-Sometimes & $\square$ 2-Always \\
\hline Restlessness & $\square 0$-Never & $\square$ 1-Sometimes & $\square$ 2-Always \\
\hline Aggressive/fighting & $\square 0$-Never & $\square$ 1-Sometimes & $\square$ 2-Always \\
\hline Bad dreams & $\square 0$-Never & $\square$ 1-Sometimes & $\square$ 2-Always \\
\hline Difficulty in deciding & $\square 0$-Never & $\square$ 1-Sometimes & $\square$ 2-Always \\
\hline Crying spells & $\square 0$-Never & $\square$ 1-Sometimes & $\square$ 2-Always \\
\hline Forgetful & $\square 0$-Never & $\square$ 1-Sometimes & $\square$ 2-Always \\
\hline Feels rejected & $\square$ 0-Never & $\square$ 1-Sometimes & $\square$ 2-Always \\
\hline Lack of confidence & $\square 0$-Never & $\square$ 1-Sometimes & $\square$ 2-Always \\
\hline $\begin{array}{l}\text { Difficulty in } \\
\text { concentrating }\end{array}$ & $\square 0$-Never & $\square$ 1-Sometimes & $\square$ 2-Always \\
\hline
\end{tabular}

\section{REFERENCES}

1. Fugelli P. The burned-out physician. Nord Med 1987;102(12):360-362.

2. Wong JG. Doctors and stress. Med Bull 2008 Jun;13(6):4-7.

3. Gabbard, G.; Menninger, R. The psychology of the physician. In: Gabbard G, Menninger R, editors. Medical marriage. Washington (DC): APA Press; 1988. pp. 11-22.

4. Notman, M. Physician temperament, psychology, and stress. In: Goldman LS, Myers M, Dickstein L, editors. The handbook of physician health. Chicago (IL): AMA Press; 2000. pp. 39-51.

5. Gautam, M. Depression and anxiety. In: Goldman LS, Myers M, Dickstein L, editors. The handbook of physician health. Chicago (IL): AMA Press; 2000. pp. 80-94.

6. Maslach, C.; Leither, MP. The truth about burnout. San Francisco (CA): Jossey-Bass Publishers; 1997. pp. 13-15.

7. Myers, M. Depression and anxiety. In:Goldman LS, Dickstein L, editors. The handbook of physician health. Chicago (IL): AMA Press; 2000. pp. 80-94.

8. Cromie, WJ. Suicide high among female doctors. Cambridge (MA): The Harvard Gazette; 2005.

9. Pearson, C. New study shows high rate of stress among doctors. Washington (DC): VOA News; 2009. [cited 2009 Sep 26]. Available from: http://www.voanews.com/ english/2009-09-26-voa3.cfm.

10. Dasgupta $H, K u m a r S$. Role stress among doctors working in a government hospital in Shimla (India). Eur J Soc Sci 2009 Sep;9(3):356-370.

11. Adshead G. Healing ourselves: ethical issues in the care of sick doctors. Adv Psychiatr Treat 2005 Sep;11(5):330-337.

12. Chambers R, Belcher J. Self-reported health care over the past 10 years: a survey of general practitioners. Br J Gen Pract 1992 Apr;42(357):153-156.

13. Forsythe M, Calnan M, Wall B. Doctors as patients: postal survey examining consultants and general practitioners adherence to guidelines. BMJ 1999 Sep;319(7210):605-608.

14. Sehlen S, Vordermark D, Schäfer C, Herschbach P, Bayerl A, Pigorsch S, Rittweger J, Dormin C, Bölling T, Wypior HJ, et al. Job stress and job satisfaction of physicians, radiographers, nurses and physicists working in radiotherapy: a multicenter analysis by the DEGRO Quality of Life Work Group. Radiat Oncol 2009 Feb;4:6-14. 